Epiphany: Vol. 7, No. 1, 2014

ISSN 1840-3719

\title{
How is Culture used as a Tool for Dissuasion of Conflict and Consensus: A Case of Sarajevo (1992-1995) Jelena Hadžiosmanović
}

\begin{abstract}
Within cities, culture and creativity have often been used as successful tools for dissuasion of conflict and consensus. Using the case study of the cultural scene in the city of Sarajevo - chiefly focusing on the period of the 1992-95 siege of the city - this paper argues that culture is an arena for creativity and resistance, but generally not an effective tool to end the conflict. I suggest that the role of arts in peace building and reaching consensus within Bosnia and Herzegovina is rather modest and its primary role is simply the artists' need to confront Beckettian "nothing to be done" while, in a truly Lafebvreian manner they, as citizens, are thus expressing their right to the city. To illustrate this, I will start with a short explanation of the history and the complexity of ethnic and cultural structure of Sarajevo. The main part of this paper will explore various examples of art forms produced in the besieged city - all examples of socially engaged art created in candlelit basements and cold, heavily damaged buildings, followed by its more peace-building role in the period after the end of the war. After providing several examples of art during the siege, I explain what might have been the reasons for such a rich cultural production during the war, using some of the theories about identity, loss of common memories and urbicide. Finally, I discuss the purpose of culture during the war and that only in a less complex conflict arts and culture could be used as tools for dissuasion of conflict and consensus. In general, the paper argues for the affirmative power of cultural production and consumption for a community, which cannot always change the reality of a situation, but provides mental relief and a symbolic performance of unity and togetherness.
\end{abstract}

Keywords: Identity; Culture; Memory; History; Urbicide.

*Jelena Hadžiosmanović, Goldsmiths, University of London; email: jelenainsarajevo@yahoo.com 
Each place has a potential to develop creativity and one can argue that the more complex a place is, the higher creative potential emerges. Florida (2005) claims that cities "have long been the vehicles for mobilizing, concentrating, and channelling human creative energy" (p. 1). Moreover, within cities, culture and creativity have often been used as successful tools for dissuasion of conflict and consensus. Nonetheless, Yudice (2003) raises a question, prompted by the September 11 attacks upon the United States: "does culture have the power to remake community when the world is thrown into crisis?" (p. 8).

Using the case study of cultural scene in the city of Sarajevo chiefly focusing on the period of the 1992-1995 siege of the city this paper argues that culture is an arena for creativity and resistance, but generally not an effective tool to end the conflict, as some - quite naively - believe. Defining art and culture is diverse depending on concepts used in different social sciences - sociology, anthropology, etc. Having in mind the difficulty of daily struggles for survival, for people in Sarajevo the closest one is probably the anthropological definition of "culture as a whole way of life" (Mayo, 2000, p. 13), but in this paper I will mostly analyse art forms created during the war.

I suggest that the role of arts in peace building and reaching the consensus within Bosnia and Herzegovina is rather modest and its primary role is simply the artists' need to confront Beckettian "nothing to be done." They needed to achieve a catharsis in order to reduce psychological stress as well as offer their stance against violence and absurdity of war. Similar to what Hayden explains in her exploration of the story of Los Angeles, in Sarajevo "each project 
deals with bitter memories [...] but shows how citizens survived and persevered to make an urban life for themselves, their families, and communities" (Hayden, 1995, p. xiv). For Sarajevo artists, creating art was the only way to gain freedom from oppression and confirm their connection and affiliation with the city. Their art, at the same time, provided a strong message to the rest of the world: "don't let them kill us", as was written on a banner held by contestants of the 1992 Miss of the Besieged Sarajevo beauty contest (Figure 1).

To illustrate this, I will start with a short explanation of the history and the complexity of ethnic and cultural structure of Sarajevo. The main part of this paper will explore various examples of art forms produced in the besieged city - the establishment of a film festival, numerous exhibitions, musical concerts, theatre plays all examples of socially engaged art created in candlelit basements and heavily damaged cold buildings. The artists' collective memory still does not allow them to deviate from conflict-related topics, which is seen in films they direct, plays they write and other activities they take part in after the end of the war - when arts and culture take on a peace building role.

Each city and its people are famous for something. War Sarajevo stands as a symbol of immense and stubborn human resistance and its people wanted to prove that the city belonged to them. As if, while creating more, the artists agreed with the theory that "the city is everywhere and in everything" (Amin \& Thrift, 2002, p. 1) and more art would create more of a city to defy and proudly stand against the enemy. Therefore, I argue for the affirmative power of cultural production and consumption for a community, which 
cannot always change the reality of a situation, but provides mental relief and a symbolic performance of unity and togetherness.

As a non-sociologist, I must emphasize that this is solely an attempt to rationalize why things happened they way they did, while drawing parallels with theories about the city, identity and memories. At the same time, this is an intimate experience of living through the events from more than a decade ago. For me, a citizen of Sarajevo, it is my own cathartic journey.

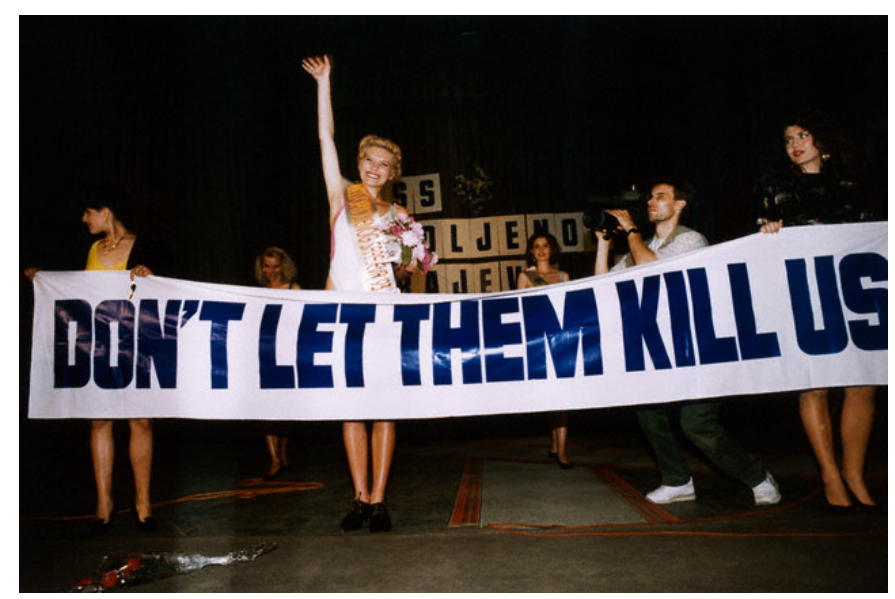

Figure 1: Miss Besieged Sarajevo

"Great cities have always been melting pots of races and cultures" (Park, 1925 cited in Florida, 2005, p. 27), and before the fall of Tito's Yugoslavia, Sarajevo was for many one of such great cities famous for its ethnic, cultural and religious diversity. The urban landscape of Sarajevo has always been extremely complex: the groups were firstly differentiated by different religious backgrounds, but "in the previous century the differences were created among main national groups" (Donia, 2006, p. 2): Bosniaks, Croats and Serbs, which was usually accordingly linked to their religious identities - 
Muslims, Roman Catholics and Eastern Orthodox, respectively. Although some people considered Sarajevo to be "an ideal of pluralism" (Sontag, 2003, p. 316), and often called it "Jerusalem of the Balkans," its once lauded multi-ethnicity and interculturalism developed into a burden to be borne by its war-troubled citizens.

The siege started in April 1992, with nationalist Serb forces bombing the city ordered not to stop "until [people] are on the edge of madness" (Bell in introduction to Edge of Madness, 1997). Suffering the longest siege of a capital city in modern history, lasting 1,395 days, the city's destiny was a perfect example of a modern war and dreadful ethnic cleansing. The number of civilians who lost their lives reached around 10,000, and the once great city became a synonym for a wasteland spreading on two sides of the Miljacka River.

And yet, those who were surviving and those who succeeded to survive until the end of the war showed unmeasured spiritual resistance and "a determination to preserve trappings of normal urban life" (Donia, 2006, p. 317). Among them, as a special community determined not to give up were Sarajevo artists. It is known that in times of political crises "[c]onflicts, as in Belfast, Beirut or Sarajevo, can sometimes create incidental innovations" (Landry, 2000, p. 148). What happened in Sarajevo certainly was not anything similar to a carefully planned rich urban solution for a project within an urban environment. It was a spontaneous and unplanned acting and rise of creativity during a crisis.

First such example is definitely the creation of the Sarajevo Film Festival. Today, it is the biggest Balkan film festival, and, additionally, a very significant film festival in Europe, with over 200 
screenings, 17 programs and over 100,000 visitors last year (information collected from Sarajevo Film Festival website). Kevin Spacey, Steve Buscemi, Michael Moore, Mickey Rourke, Morgan Freeman, Wim Wenders, Angelina Jolie and Brad Pitt are just few names from an enviably successful list of Festival's guests over the years. However, it certainly was not always like this and the Festival's founders have not thought that it could become such a huge event primarily because they were not sure if they would still be alive by the end of the first screening.

When the war broke out, electricity supply was cut, and, furthermore, it was too risky to gather in larger numbers and consequently become a better target for shelling. These were the main reasons for all movie theatres to close when the siege started. Susan Sontag (2003) described: "Outside a boarded-up movie theatre next to the Chamber Theatre is a sun-bleached poster for The Silence of the Lambs with a diagonal strip across it that says DANAS (today), which was April 6, 1992, the day moviegoing stopped" (p. 302).

However, as Dani Magazine reports (Seksan and Hadzovic, 2002), after the first shock, people started organizing various cultural events and two cinemas opened: Apollo in 1993 and Radnik in 1994. They played what they had, usually films from private collections, later retrospections or even newer films brought by foreign journalists. "Obala" Open Stage continued with activities during the war in cooperation with Sarajevo's Academy of Performing Arts, and Dani Magazine, and organized screenings in Apollo. Screenings were operated through a generator; ticket - one German mark or one cigarette, and it was always full. It is said Basic Instinct was amongst 
the most popular films, as "everyone wondered if you could really see it" (Seksan \& Hadzovic, 2002). A visitor to this film explains: "I was scared to death, running all the way with my cousin. It was very dangerous, but we did it" (Turan, 2002, p. 90).

The first Sarajevo Film Festival opened as a logical sequel of the previously organized screenings, on 25 October 1995 - near the end of the war - with today's jailed Iranian film director Jafar Panahi's film White Balloon. Film directors Milcho Manchevski (Macedonia) and Leos Carax (France) were Festival's guests and dragged $40 \mathrm{~kg}$ of film rolls over the Mount Igman - the only way they could access Sarajevo. The foundation of the festival was only a continuation of all other efforts filmmakers and filmgoers did prior to it, and festival director Mirsad Purivatra recalls it was done "under extremely difficult conditions but with incredible enthusiasm and a dream of freedom" (Purivatra cited in Zuvela, 2011). The creation of a film festival during the war "could have seemed more like a bizarre act of resistance than a real film festival" (People Building Peace website). Nevertheless, it was real. Thirty-seven films were shown, some on VHS, some on film, and every day the screenings were packed with cineastes $-15,000$ in total. One of the main organizers Haris Pasovic explains:

there are many things you can live without, food, etc., but you need film or arts for the magic. In the war it was particularly powerful to be watching films and be able to be transported to another world and also release emotions through the film (as many kept them bottled up during the war) (Zelizer, 2003, p. 69).

Musicians ceaselessly appeared in public. Sarajevo String Quartet never stopped performing or rehearsing. Concerts were usually held during the day because of the curfew and lack of 
electricity. During the siege the members kept changing because some left the city and some lost their lives. The quartet's leader Dzevad Sabanagic admits he never thought about leaving the city: "It's unthinkable for me. It would be like leaving a sick parent or child. I never even think about it [...] My country is crying now. It carries a heavy burden. Can you imagine abandoning a sick child?" (CNN World, 1995) he explains.

The rehearsals were held wherever they had a chance to meet - usually at someone's apartment and later, from 1993, when they started the official cooperation with the Chamber Theatre and were then called "Chamber Theatre 55 String Quartet", they could practice at the theatre's premises (information collected from Sarajevo String Quartet website). During the siege, they held over 250 concerts, always playing, avoiding shells and pieces of shrapnel; never giving up.

I still remember well a concert we held in a church in New Sarajevo Municipality in 1993. Outside it was around $-17^{\circ} \mathrm{C}$ and inside of the church $-20^{\circ} \mathrm{C}$. After the service we held a concert; people sat in furs, coats, and no one moved - they asked from us to play encore several times (Seksan \& Hadzovic, 2002).

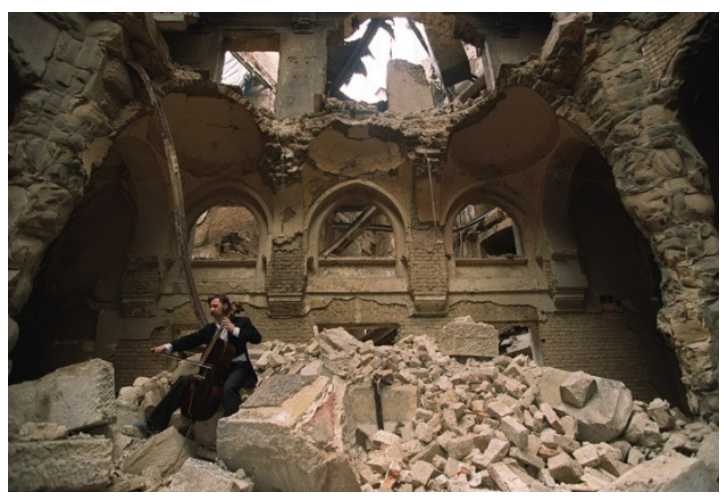

Figure 2: Vedran Smajlovic performing surrounded with ruins of the burned City Hall building 
Even when people got scared during heavy shelling and would start leaving, the quartet never stopped playing. UN's Peacekeeper Anne Marie du Preez Bezdrob, recalls in her book Sarajevo Roses: War Memoir of a Peacekeeper a visit to a concert by the quartet in 1993. She was impressed by these intrepid people, both performers and the audience, and felt somewhat guilty for shaking under her flak vest (which no one else had). She writes:

Serb shells were ripping apart their city and their lives, but their souls were their own [...] As an intensity of the bombing increased, small groups started leaving. The quartet kept playing as though nothing was amiss; their faces calm and composed, their practiced hands unwavering (du Preez Bezdrob, 2004, pp. 162-63).

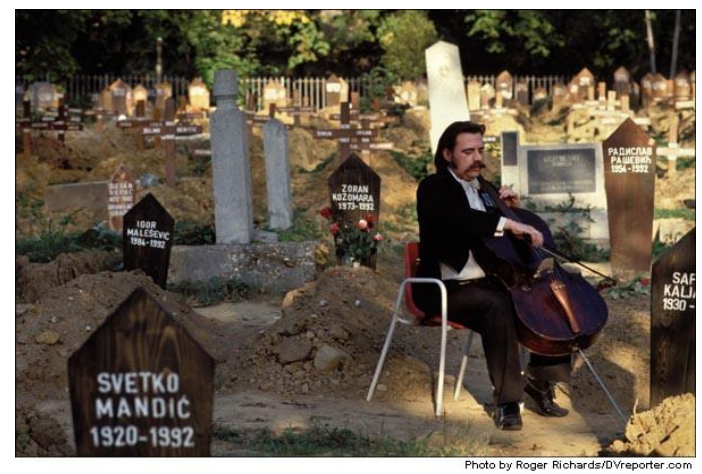

Figure 3: Vedran Smajlovic performing at a Sarajevo cemetery

Another musician Vedran Smajlovic (who played for Sarajevo String Quartet as well as for the National Theatre, Sarajevo Opera, the Sarajevo Philharmonic Orchestra and the Symphony Orchestra of RTV Sarajevo), also known as "The Cellist of Sarajevo," became a symbol of moral undefeatedness all over the world. When a mortar hit a breadline in May 1992, it killed 22 civilians, the cellist's close neighbours and friends. Smajlovic, wearing his concert dress, decided to mourn and honour the innocent by playing for 22 consecutive days on different city locations - usually the ruins, the streets or cemeteries 
of Sarajevo (Figures 2 and 3). "Smajlovic's quixotic requiem became an irresistible symbol of European civilization under siege" (The Daily Beast, 1993), and his performance of Albinoni's Adagio in G Minor filled the air in the midst of the battle and made a stand against war and violence.

Two smaller theatres remained open throughout the war: Youth Theatre and Chamber Theatre 55, and during the war SARTR or Sarajevo War Theatre (Sarajevski ratni teatar) was founded in 1992. Actors and associates of the existing professional theatres in Sarajevo gathered around SARTR and gave around 2000 performances during the siege (information collected form SARTR website). Among many other titles, Youth Theatre produced a premiere of Samuel Beckett's Waiting for Godot, directed by Susan Sontag, who visited Sarajevo on several occasions during the war, and staged the play in 1993.

When asked why she had chosen that particular play Sontag replied: "Beckett's play, written over forty years ago, seems written for, and about, Sarajevo" (Sontag, 2003, p. 300). Classical tragedies usually have a social purpose. This play might not have as strong antiwar message of the Theatre of the Oppressed where authors like "Brecht aimed to provoke precisely such reflections - as the prelude to action for social change, rather than simply wanting to inspire empathy with his characters" (Mayo, 2000, p. 104). Sontag unassumingly wanted to do a small contribution and make the actors and the audience feel normal, at least for the duration of the performance. 


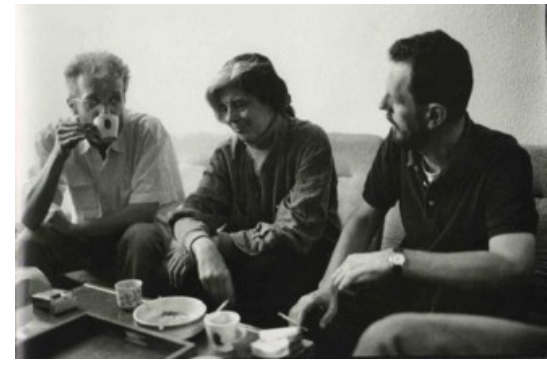

Figure 4: Pasovic, Sontag and Grebo during one of Sontag's visits to Sarajevo

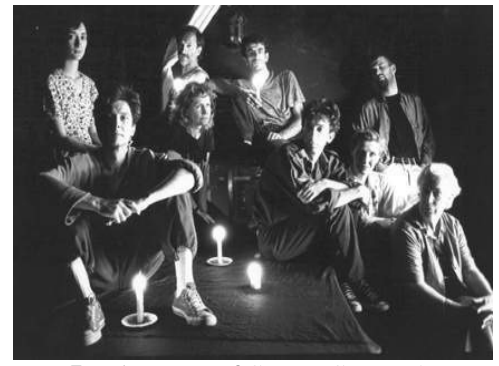

Figure 5: The cast of Susan Sontag's production :ting for Godot, 1993

Sontag describes how the entire group was struggling during rehearsals without heating and light, they lacked appropriate props, the actors were malnourished and could not memorise the lines easily and would get tired quickly. Nevertheless, the play premiered with twelve candles on the stage, and actors of all ethnic and religious groups delivered the lines without problem. They acted as friends, fellow citizens.

"In Sarajevo, as anywhere else, there are more than a few people who feel strengthened and consoled by having their sense of reality affirmed and transfigured by art" (Sontag, 2003, pp. 301-302). To list all artistic creations would be impossible, and the above mentioned examples serve here just as an illustration of a vast quantity of events during the siege: poetry days, Eurovision song contest, documentaries and feature films made by SAGA production house, International Festival 'Sarajevo Winter', chess competitions, football matches between $\mathrm{B} \& \mathrm{H}$ and UNPROFOR forces, children plays and costume parties, etc.

And that was not all. Each and every citizen contributed to the city's spirit never to be defeated. Sarajevans kept their humour many jokes from the war are still told, most of them in the famous 
black humour style (for example, they were joking that Americans did not send the air raid but at least they could have sent a pigeon since it could be cooked and eaten). A group of people contributed to FAMA's publication of Sarajevo Survival Guide - with inventive solutions for survival in a besieged city, including a list of recipes mostly explaining how to make something out of nothing (with a warning to use the cookbook at your own peril). Even the members of the Bosnian army showed their ingenuity when "borrowing" four tanks from the Sarajevo museum and returning them at the end of the war with a note they were very useful and they had no complains while using them (Donia, 2006, p. 311). Such are Sarajevans, never losing their high spirits, even during the hardest times.

After becoming acquainted with the quantity of cultural production during the siege of Sarajevo, one cannot but wonder: what makes you want to go to a film screening or a performance of a theatre play when your basic human needs are cut: you live without water, food, electricity, medical supplies or connection with the rest of the world? Moreover, what makes you create culture, when the whole cityscape around you seems to be falling to pieces?

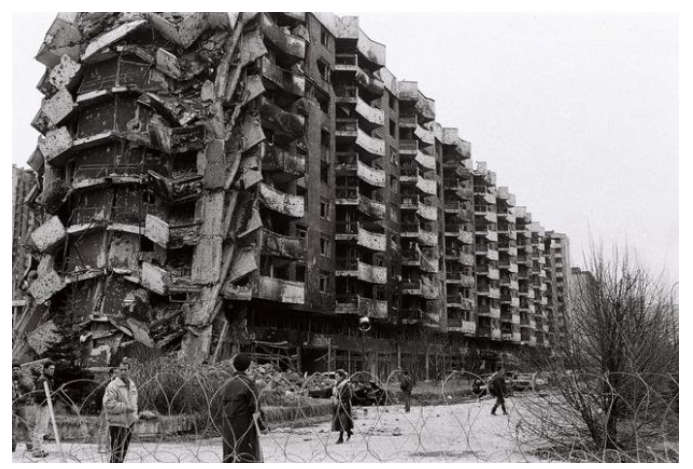

Figure 6: Destruction of Sarajevo's cityscape 
"Social scientists and psychologists have noted that preserving a sense of normalcy is a common response to violence" (Maček, 2000, cited in Donia, 2006, p. 318). Artists' primary role within a society is to create art, which was, according to this theory, the most "normal" reaction to the war around them. Additionally, Hayden believes that "when the urban landscape is battered, important collective memories are obliterated" (Hayden, 1995, p. 9), so in order to protect their memories and the memories of their city from disappearance and destruction, the artists simply decided to create more than ever - in order for their works to outlive them, and memories to be preserved. "A cityscape is not made of flesh" (Sontag, 2004 , p. 8) but destroyed buildings could almost be added to the number of casualties in Sarajevo (Figure 6). The people of Sarajevo made it clear that the enemy could crumble the entire cityscape, but not its people - the core of the city. After all, city is "a living organism, not a machine" (Landry, 2000, p. 8).

Significantly, it seems the enemy was thinking similarly in terms of the importance of collective memories and identity. As Donia (2006) explains in his book on Sarajevo, during several first months, The Army of the Bosnian Serb Republic did not target most populated places, or places which were strategically and artillery-wise significant for Sarajevan inhabitants. They turned their focus on all most visible manifestations of culture and religion and thus the first major victims of the heavy shelling from the surrounding hills were places like the National and University Library of Bosnia and Herzegovina situated in the old City Hall building Vijećnica (which was the home for around 3 million books - proofs of mutual co- 
existence of the peoples in Bosnia and Herzegovina), the Olympic Museum, the Oriental Institute, the main daily newspapers (Oslobodjenje) building as well as churches, mosques and the old synagogue. Landry (2000) explains how "[c]ultural heritage is the sum of our past creativities and the results of creativity is what keeps society going and moving forward" (p. 6). All these buildings, burned to ashes, were cultural symbols of the city and by destroying these symbolic values a part of the city's significant history of co-existence and common memories would be deleted, which would prevent it to advance and prosper. In a way, as historian Robert Donia explains, it was a true "memoricide" (Donia, 2006, p. 314).

Besides it being a "memoricide", Martin Coward 'revives' the term "urbicide" relating it to the 1992-1995 War in Bosnia, and describes it as the "widespread and deliberate destruction of the urban environment" (Coward, 2008, p. xii). He focuses primarily on the city of Mostar and the destruction of the Old Bridge (Stari most), built during the Ottoman time and heavily shelled until it collapsed into the river of Neretva. Coward argues that from an anthropocentric perspective it is difficult to give such importance to destruction of buildings, but one has to understand that it was the integral part of the destruction of cultural property to perform the ethnic cleansing process. The attachment to and importance of the space and place is clear from a Croatian writer Slavenka Drakulic's 'obituary' she dedicated to the Old Bridge in Mostar, when describing her reaction to photographs of a Bosnian woman with a cut throat and the image of the destroyed bridge. The answer reads:

Why do I feel more pain looking at the image of the destroyed bridge than the image of the woman? Perhaps it is because I see my own 
mortality in the collapse of the bridge, not in the death of the woman [...] A dead woman is one of us - but the bridge is all of us. (Drakulic, 1993, cited in Coward, 2008, p. 11)

Similarly, Michael A. Sells describes in his book The Bridge Betrayed: Religion and Genocide in Bosnia a comparable reaction by a Sarajevan woman who lived there during the war and saw the cityscape destruction as well as numerous casualties in a hospital. Sells notices that

the burning of the library struck her with special horror. In the fire of the National Library, she realized that what she was experiencing was not only war but also something else. The centuries of culture that fell back in ash onto the besieged city revealed a secret. (Sell, 1996, cited in Coward, 2008, p. 1)

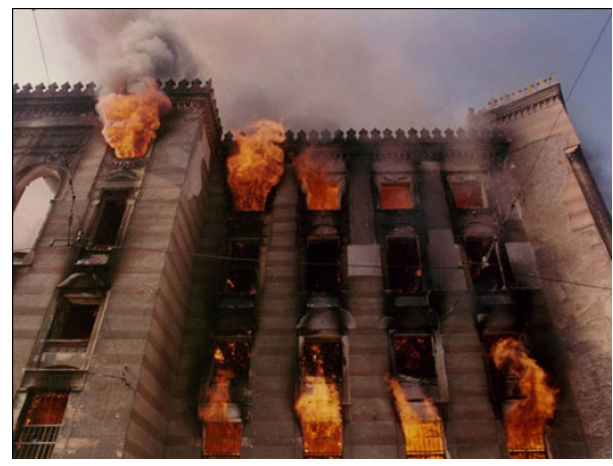

Figure 7: The City Hall (Vijećnica) burning after heavy shelling in 1992

One of the highest achievements of Bosnian and Herzegovinian culture was disappearing in fire and together with it shared history and memories of co-existence. That hurt some people more than the injuries on their bodies - which could eventually heal. So, to come back to the artistic creation during the war - it must be that, stimulated by the destruction of the collective memories of the city, the citizens answered with a creative endeavour taking them to creation of new memories.

And which were the memories that the citizens were trying to 
protect? Which identity, and whose city was it? A nation has been defined as a society that "occupies a particular territory and includes a common identity, history and destiny (Johnson, 1995, p. 188). In that sense, due to the complex ethnic structure, the articulation of national or ethnic identity was quite difficult and problematic for people in Bosnia and Herzegovina, especially for those coming from mixed marriages - many of whom lived in the capital. Some of them simply declared only their Yugoslav identity (and, absurdly, some still do). Just as in the case of Cieszyn Lutherans in Poland described in Marian Kempny's study about their locality, in war Sarajevo "national identification ceased to be a decisive factor in the process of identity construction" (Kempny, 2002, p. 66). Communities based on ethnicity, religion, age or social statuses were not the primary ones. Of course, there were "connections arising out of shared experiences, relationships, histories, territories and practices" (Ibid., p. 15). Nevertheless, the people of Sarajevo created a new community based on shared locality, i.e. the city, but at the same time they shared same interests and experience. As Popple (2003) nicely explains, "communities of interest can be based upon people sharing a common condition or problem" (p. 39). Community was never precisely defined, but here it is worth noting Anthony P. Cohen's (2002) observation that "[it] has become a way of designating that something is shared among a group of people at a time when no longer assume that anything is necessarily shared" (p. 169, original italics). The sameness of the people of Sarajevo was the war oppression. Thus, no matter how much the issue of identity was problematic for Sarajevans before the war, they all agreed in one - that was their city and they 
belonged to it, regardless of them being Bosniaks, Croats or Serbs, since there were surely members of all three major ethnic groups defending it - on the front lines, or, as previously mentioned artists, by creating new city culture and memories. Their primary important aspect of identity was that they were citizens of Sarajevo - the city as it used to be before the destruction. Sarajevo as a place became extremely important for all those people who remained there and created strong social bonds between themselves and the city.

We can see this in the example of The Cellist of Sarajevo. In an interview for New York Times Smajlovic said: "My mother is a Muslim and my father is a Muslim, but I don't care. I am a Sarajevan, I am a cosmopolitan, I am a pacifist. I am nothing special, I am a musician, I am a part of the town. Like everyone else, I do what I can” (People Building Peace website).

Of course, here one has to clarify that "citizen" as a term used in the text above relates to an inhabitant of a city and not member of a state, and professor Painter affirms "that there is no simple correspondence between citizenship and national identity" (Painter, 2005, p. 6). He furthermore explains how "[g]eographies of citizenship have become increasingly dislocated from those of national belonging" (ibid), which coincides with the priority given to this particular definition of "citizen" in this case, due to the complexity of national identity. It might be that the people of Sarajevo linked citizenship with the city specifically because that identity was the safest one for all entity groups. 
Another link among the people was their cultural identity. There are different ways to define cultural identity according to Hall, and the

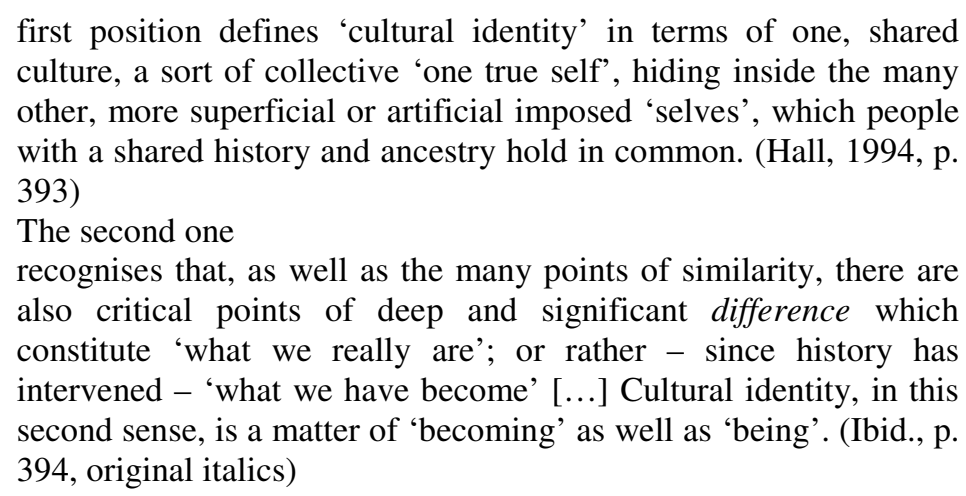

One can say that, during the war, Sarajevans who kept many different identities within themselves developed the 'collective self' beyond the differences among them and transformed their identity to a common one. One way or another, they were all extremely shaped by the cultural legacy of their ancestors and found the "common language" to unite them in their difference. "For some, culture represents a protective 'shield' to guard them against unwelcome change, for others it represents a 'backbone' with which to face the future" (Landry, 2000, p. 39). In Sarajevo's case, it might have been both - culture guarded the citizens from the horrors around them as well as gave them some hope that one day - hopefully soon - this will all be in the past. In the end, what mattered most to them was not so much what they were, but what they were not - enemies, "them", "others".

Another forced identity to which Sarajevo citizens were thrown to was the Balkan identity. Trying to remove the popular tag 
"the bloody Balkans", when organizing events like, for example, Sarajevo Film Festival during the siege, the citizens of Sarajevo saw it as "a way of reminding the world that this city fought a war because it believed it had earned a place in that cosmopolitan artistic cosmos" (Turan, 2002, p. 107). Feeling abandoned by the rest of the (mostly Western) world, they wanted to revive their European identity, or, even broader, be part of the bigger world again.

Finally, after explaining various reasons which triggered heightened culture productivity during the war in Sarajevo, we come back to the question from the beginning of this essay: "What is the role of culture in times of ongoing crisis, as has been the case in Bosnia and Colombia?" (Yudice, 2003, p. 338). Can culture ease the conflict? Does it have the power to stop the war?

The Oxford English Dictionary, among other definitions, describes war as "any kind of active hostility or contention between living beings, or of conflict between opposing forces or principles" (The Oxford English Dictionary - Vol. XII, 1933, p. 80), and warfare as "the act or state of conflict" (Ibid., p. 97) which defines 'war' and 'warfare' as a type of conflict. Looking back at history and knowing what happened in the case of Sarajevo, one knows that, no matter how strong it was, cultural activity did not stop the conflict, it did not stop the war. Why did it fail, and should we call it a failure?

I believe it did not fail, because its purpose was not to accomplish any bigger impact than it was. Arts are often used as a tool for conflict resolution and reconciliation. However, once the conflict is brought to an extreme, as in the case of Sarajevo war, we can only talk about arts helping the community keep sanity, show 
resistance and serve as a confirmation of people's city identity. Once the escalated violence and conflict is kept under control, arts take on another role and help peacekeeping and reconciliation. Of course, the example of Sarajevo is not sui generis. Any severe catastrophe - war, or a natural disaster, would have similar results. It might be that the case of Sarajevo is simply extremely complex, as filmmaker Srdjan Karanovic puts in plain words: "Here history is very complicated, there is conflict and remembrance from every period" (Karanovic cited in Turan, 2002, p. 91). Nevertheless, it used to be something extremely positive in past, and Sarajevo-born theatre director Haris Pasovic tried to explain to Susan Sontag while they worked on Waiting for Godot together: "You can't imagine what it used to be like here. It was paradise" (Pasovic cited in Sontag, 2003, p. 316). Even foreigners understood the city's uniqueness and, to use the words of film director Paul Alden Robinson "[b]efore the war it was the one place where people got along, a combination of small town openness and warmth and big city sophistication; it was the best vision we have of ourselves" (Turan, 2002, p. 93). Remembering this almost idealised picture of the city possibly motivated artists even more in their struggle to keep the city's former spirit alive.

Many journalists and war photographers hope that showing the rest of the world the horrors of war would make a significant change. But the photograph "The Napalm Girl” by Nick Ut did not end the Vietnam War. Susan Sontag' play did not help end the war in Sarajevo, as well as all the activities of Jews during the WW2 did not have any conflict resolution aim. Jean Baudrillard wrote:

The people of Sarajevo are not bothered by such questions. Being where they are, they are in the absolute need to do what they do, to 
do the right thing. They harbour no illusion about the outcome and do not indulge in self-pity. This is what it means to be really existing, to exist within reality [...] This is why they are alive, while we are dead. (Baudrillard, 1994)

All creative solutions within arts and culture section during the war were not there to solve problems and were not catalysts for change. But later, they did and still do play a significant role in peacekeeping and reconciliation processes.

Since the war ended, Sarajevo Film Festival is dedicating a special part of their program to children, "which started when director Purivatra realized that the four-year siege meant that a generation of children hadn't had the opportunity to see the movies on the big screen" (Turan, 2002, p. 108). Buses bring children from all over Bosnia and Herzegovina - both entities - to children matinee program, similar to the later constructed idea of Kids' Festival organized every year since 2004. Sarajevo Film Festival brings some of its program outside of the capital too, to areas where people might not even have a cinema to visit - all having "a special role to play in binding the wounds of wars, advancing regional cooperation and reconciliation, and promoting peace and human rights" (People Building Peace website).

Some projects exist so that the horrors of war do not fall into oblivion. Young actress Zana Marjanovic leads a project in the last couple of years, where actors and ordinary citizens take part in a performance where they count the number of victims of the Srebrenica massacre. Artists still carry memories which need to be told. This might be the main reason why they mostly reflect the war in their work. Most of the post-war films are about the war or 
consequences of war. An example could be the recent film by contemporary artist Sejla Kameric 1395 Days without Red, in which the main character, played by Spanish actress Maribel Verdú, is reliving the experience of the trauma of the siege. It is her individual journey through the collective memory of the city.

"Cities have always been, and will always be, places of heterogeneity" (Bridge \& Watson, 2000, p. 255). In this paper, I tried to illustrate the complexity of Sarajevo's heterogeneity and the search of its war troubled citizens for identity within the city. In a truly Lafebvreian manner, the citizens expressed their right to the city and I argue that exactly because of the strength of the urbicidal affects, Sarajevo's citizens, and especially artists, were fighting against this war with strong cultural production in the besieged city.

After providing several examples of art during the siege, I explained what might have been the reasons for such a rich cultural production during the war, using some of the theories about identity, loss of common memories and urbicide. Finally, I discussed the purpose of culture during the war and that only in a less complex conflicts arts and culture could be used as tools for dissuasion of conflict and consensus.

Sometimes it seems culture in Sarajevo is struggling more today than it did during the siege - due to the lack of budget, many institutions might close their doors to public, many artists left the city, and those who are still there, in these times of social poverty and more global problems, are hoping for affectionate audience as was in the time of the city's siege. On one occasion, actor and director of Sarajevo's Youth Theatre Nermin Tulic, who himself became a 
paraplegic as an early victim of the war, declared that he missed the war because then we were all better people (Seksan and Hadzovic, 2002). Anyhow, it is certain that "[c]ulture helps us to adapt to change by anchoring our sense of being; it shows that we come from somewhere and have a story to tell; it can provide us with confidence and security to face the future" (Landry, 2000, p. 39), which was exactly the role of culture during the siege in Sarajevo. Thus, Wilde's belief that "all art is quite useless" does not hold ground. As described in People Building Piece II,

It is doubtful whether Vedran Smailovic managed to save a single life, shorten the Bosnian war, or speed the end of the siege of Sarajevo by even one day. Almost certainly, his brave actions made little impression on the Serb gunners who continued their merciless shelling of Sarajevo from the hilltops surrounding the city; if they were aware of his existence at all. He did not see himself as a peacebuilder. Yet his story has been often repeated and his actions have been held up to the world as a symbol of inspiring courage and nonviolent resistance in the face of horrible violence and human suffering (People Building Peace website).

The time to grasp the entirety of purposes and consequences of artistic production during the war in Sarajevo has not yet ended and as long as there are such inspiring people as those described in this essay it gives hope in the brighter future of this "crazy but charismatic town" (Purivatra cited in Turan, 2002, p. 93).

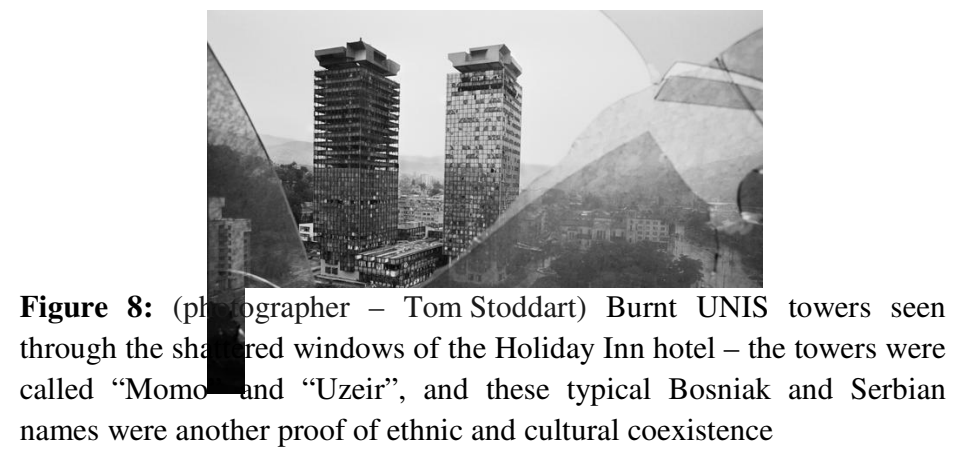




\section{References}

Amin A. and Thrift N. 2002. Cities: Reimagining the urban. Cambridge: Polity Press.

Andreas, P. 2008. Blue helmets and black markets: the business of survival in the siege of Sarajevo. Ithaca: Cornell University Press.

Baudrillard, J. (2004). 'No Reprieve For Sarajevo' Liberation, 8 January. Retrieved from:

http://www.uta.edu/english/apt/collab/texts/reprieve.html (Accessed: 22 December 2011)

Bridge G. and Watson S. 2003. 'City Differences' in Bridge G. and Watson S. (Eds.) A companion to the city. Oxford: Blackwell Publishers Ltd.

Cohen, A. 2002. Epilogue. In: Amit, V. (ed.) 2002. Realizing community: concepts, social relationships and sentiments. London: Routledge. Ch.9.

Coward M. 2009. Urbicide - the politics of urban destruction. New York: Taylor and Francis Group, Routledge, retrieved from URL http://www.ewidgetsonline.com/dxreader/Reader.aspx?token=v+PpHsyYi WdiGCmc2vu0Vw\%3d\%3d\&rand=1838137898\&buyNowLink=\&page= \&chapter $=$

Donia, Robert J. 2006. Sarajevo, a biography. London: Hurst \& Company.

du Preez Bezdrob, A. M. 2006. Sarajevo roses: war memoir of a peacekeeper. Johannesburg: Struik Publishers.

Florida, R. 2004. The rise of the creative class and how it's transforming work, leisure, community and everyday life. New York: Basic Books.

Florida, R. 2005. Cities and the creative class. New York: Routledge.

Hall, S. 1994. 'Cultural Identity and Diaspora' in Williams P. and Chrisman L. (Eds.) Colonial discourse and post-colonial theory, a reader. London: Pearson Education Limited.

Hayden, D. 1995. The power of place: urban landscapes as public history. Cambridge: MIT Press.

Jenks, C. 1993. Culture. London: Routledge.

Johnson, A. 1995. The Blackwell dictionary of sociology. Oxford: Blackwell.

Kempny, M. 2002. Cultural islands in the globalising world: community-cumlocality of the cieszyn silesian lutherans. In: Amit, V. (ed.) (2002). Realizing community: concepts, social relationships and sentiments. London: Routledge. Ch.4. 
Landry, C. 2000. The creative city: a toolkit for urban innovators. London: Earthscan.

Malcolm, N. 1994. Bosnia, a short history. London: Pan Books.

Mayo, M. 2000. Cultures, communities, identities: cultural strategies for participation and empowerment. New York: Plagrave

Murray, J. et al. (Eds.) 1933. The Oxford English dictionary Vol. 12: V-Z. Oxford: Clarendon Press.

Seksan V. and Hadzovic S. 2002. 'Trijumf volje’ Dani Magazine (no. 251), 5 April. Retrieved from:

http://www.bhdani.com/arhiva/251/t25124.shtml (Accessed: 21 December 2011).

Sells, Michael A. 1996. The bridge betrayed: religion and genocide in Bosnia. London: University of California Press.

Sontag, S. 2003. Where the stress falls. London: Vintage.

Sontag, S. 2004. Regarding the pain of others. New York: Picador.

Stoddart, T. 1997. Edge of madness: Sarajevo, a city and its people under siege / photographs by Tom Stoddart and Alastair Thain. London: South Bank Centre

Turan, K. 2002. Sundance to Sarajevo: film festivals and the world they made. London: University of California Press, Ltd.

Yudice, G. 2003. The expediency of culture: uses of culture in the global era. London: Duke University Press.

Zelizer, C. 2003. The role of artistic processes in peace-building in BosniaHerzegovina. In: Peace and conflict studies, volume 10, 2. Fall 2003 (pp. 62-75). Retrieved from: http://shss.nova.edu/pcs/journalsPDF/V10N2.pdf (Accessed: 22 December 2011)

Zuvela, M. 2011. 'Sarajevo Film Festival awards jailed Iranian director' Reuters, U.S Edition, 22 July. Retrieved from: http://www.reuters.com/article/2011/07/23/us-bosnia-festivalidUSTRE76M07520110723 (Accessed: 22 December 2011) 